\author{
Maciej Barczewski ${ }^{1}$, Sebastian Sykuna ${ }^{2}$ \\ University of Gdańsk
}

\title{
Improving Global Public Health: Responsiveness to Public Interest Considerations in Intellectual Property Law
}

\section{Introductory remarks}

In 1994, as a result of negotiations taking place within the framework of the General Agreement on Tariffs and Trade, the World Trade Organization (WTO) was established and its members committed, among others, to put in place and harmonize minimum standards of intellectual property protection. One of the annexes to the Agreement establishing the World Trade Organization ${ }^{3}$ was the Agreement on Trade Related Aspects of Intellectual Property Rights (TRIPS) ${ }^{4}$, imposing upon WTO Members an obligation to provide patent protection for any inventions, in all fields of technology. Given the deep asymmetries between WTO Member States in terms of their development, concerns were raised that it will result in a substantial reduction in availability of medicinal products 5 .

Undoubtedly, the monopoly enjoyed by the pharmaceutical industry based on intellectual property rights is fundamental to the problem of access to medicines, particularly in the developing and least developed countries ${ }^{6}$. On the one hand, patents encourage

\footnotetext{
ORCID number: 0000-0001-6083-7249. E-mail: maciej.barczewski@prawo.ug.edu.pl

ORCID number: 0000-0002-2582-612X. E-mail: sebastian.sykuna@prawo.ug.edu.pl

Agreement establishing the World Trade Organization (WTO) prepared in Marrakesh on 15 April 1994 (Polish title: Porozumienie ustanawiające Światową Organizację Handlu (WTO) sporządzone w Marakeszu w 15.04.1994 r., Dz. U. z 1995 r. Nr 98, poz. 483 ze zm.), hereinafter: "WTO Agreement".

4 The TRIPS Agreement text was published in the Announcement of the Ministry of Foreign Affairs of 12 February 1996 in the matter of publishing annexes to the Agreement establishing the World Trade Organization (Polish title: Obwieszczenie Ministra Spraw Zagranicznych z 12.02.1996 r. w sprawie publikacji załączników do Porozumienia ustanawiającego Światową Organizację Handlu, Dz. U. z 1996 r. Nr 32, poz. 143).

M. Barczewski, Intellectual Property Rights in the WTO and Access to Medicines, Gdańsk 2016, pp. 12-13.

6 Obviously, intellectual property rights are not the only determinant of medicines availability - the level of medical infrastructure development, distribution capabilities, and the presence of qualified medical personnel, among others, are as important in this respect. In addition to legal protection, drug prices are also affected by factors such as market structure, demand, pricing policy, or competition protection. See: The impact of the Agreement on Trade-Related Aspects of Intellectual Property Rights on Human Rights. Report of the High Commissioner (E/CN.4/Sub.2/2001/13), United Nations Economic and Social Council, 27 June 2001, p. 43; K.E. Maskus, Intellectual Property Rights in the Global Economy, Washington DC 2000, pp. 160-161. Compare with D. Matthews, TRIPS Flexibilities and Access to Medicines in Developing Countries: The Problem with Technical Assistance and Free Trade Agreements, "European Intellectual Property Review" 2005/11, p. 420ff; Prescription for Healthy Development: Increasing Access to Medicines, Report of the Task Force on HIV/AIDS, Malaria, TB, and Access to Essential Medicines, Working Group on Access to Essential Medicines, United Nations Millennium Project, Sterling (VA.) 2005, p. 5.
} 
innovation by securing inventors' "exclusive rights", i.e. property rights. This serves public interest in the same way that all property rights serve public interest. The promise of an exclusive right in the fruits of one's labors incentivizes people to invest and create new valuable assets ${ }^{7}$. On the other hand, patents give the exclusive right to grant or refuse permission to manufacture, use, sell or import products with the protected solution. They allow patentees to determine pricing policy and control product distribution, and consequently hinder marketing of competitive goods. For this reason, drug manufacturers have been seeking to strengthen legal protection of their intellectual property, particularly in the field of patent protection.

As noted by Sol Picciotto, the main problem with the TRIPS Agreement is its strong emphasis on intellectual property rights as private rights, subject to only a few limited exceptions to protect the public interest ${ }^{8}$. Therefore, over the past few years the WTO Council for Trade-Related Aspects of Intellectual Property Rights recognized that there is a growing concern about an imbalance between intellectual property and public interest. Some of its members pointed out, with regard to health technologies, that without sufficient use of balancing exceptions and limitations to protect the public interest, patents and related monopoly rights in test data permit companies to maintain high prices and aggravate the crisis of access around the world, where many patients cannot afford medicines, and force governments with limited health budgets to ration health care . Consequently, more than 20 years after the adoption of the TRIPS Agreement, there is a need for discussion in the TRIPS Council on the relationship between intellectual property rights and the public interest and to broaden the understanding of how the IP system can be more responsive to public interest considerations ${ }^{10}$.

\section{The theoretical scope of the concept of public interest}

The concept of public interest has never been based on a universal legal definition. Being quite an extensive concept, public interest gains meaning in certain conditions and time. Its denotation depends on the social context in the sense of achieving specific values accepted and desired in a given society at a given time. Hence, public interest is being redefined on an ongoing basis and subjected to continuous analysis, re-evaluation and assessment ${ }^{11}$.

Early concepts of the public interest were based on the opposition between interests of the individual and public interests. Only the doctrine of the liberal rule of law and the concept of public subjective rights formed the basis for analysing the position of the individual in the state and the nature of its interests ${ }^{12}$.

P.R. Michel et al., Putting the Public Back In "Public Interest" in Patent Law, "Regulatory Transparency Project of the Federalist Society”, https://regproject.org/wp-content/uploads/RTP-Intellectual-Property-Working-Group-Paper-Public-Interest.pdf, accessed on: 5 May 2020, p. 4.

8 S. Picciotto, Private Rights vs. Public Interests in the TRIPS Agreement, in: Proceedings of the Annual Meeting (American Society of International Law), Cambridge 2003, p. 171.

$9 \quad$ Intellectual Property and the Public Interest. Communication From Brazil, China, Fiji, India And South Africa (IP/C/W/630), WTO Council for Trade-Related Aspects of Intellectual Property Rights, 6 June 2017, pt. 9.

10 Intellectual Property and the Public Interest... (IP/C/W/630), pt. 10.

11 A. Borkowski, Interes publiczny a partnerstwo publiczno-prawne [Eng. Public Interest and Public-Legal Partnership], in: J. Blicharz (ed.), Prawne aspekty prywatyzacji [Eng. Legal aspects of privatization], Wrocław 2012, p. 444.

12 A. Żurawik, ,Interes publiczny”, ,interes spoteczny” $i$ „,interes spotecznie uzasadniony” [Eng. "Public Interest”, "Social Interest" and "Socially Justified Interest”], "Ruch Prawniczy, Ekonomiczny i Socjologiczny” 2013/2, p. 60. 
It was discovered, however, that in practice there are situations of not so much opposing, but rather of combining the individual interest and the public interest. Public interest began to appear as a complex category, consisting of elements previously rejected as its components. The "mathematical" concept, where it was assumed that public interest is the sum total of private interests, has lost its importance ${ }^{13}$. Moreover, it is generally accepted that the broad concept of general good or public interest cannot be formed solo, but that protection of the individual is covered under the general good. There can be no general good that would not include individual freedom as one of its essential elements ${ }^{14}$.

In the approach to the understanding of the public interest, one can also see the dilemma of whether to give the public interest an axiological basis tied to underlying values, or a phraseological basis tied to goals or related to needs ${ }^{15}$. According to Alison Slade,

the "public interest" is a phrase often used to rationalize political, governmental, and legal decision making at both the national and international level. Yet, it is a concept that appears devoid of a precise definition (...). It is broadly understood to convey the message that the action or inaction in question has been undertaken because society as a whole will derive a benefit. (...) National perceptions of common well-being and the philosophical origins of the public interest inevitably vary amongst states and are tied to economic, cultural, political, and historical influences that are as numerous as they are variable ${ }^{16}$.

Regardless of the use of the concept of public interest in a legal text, similar terms are used alongside it, such as the common interest, social interest or socially justified interest ${ }^{17}$. Unfortunately, such legislative measures do not make it easier for lawyers to clearly define the term "public interest", because they often have to deal with additional interpretation issues. Problems arise already at the stage of linguistic interpretation, when the interpreting party must become involved in important and sometimes extremely complicated considerations regarding the prohibition of synonymous interpretation or the directive of terminological consequence ${ }^{18}$. Without going into the

13 M. Wyrzykowski, Pojęcie interesu spotecznego w prawie administracyjnym [Eng. The Concept of Social Interest in Administrative Law], Warszawa 1986, pp. 30-31.

14 M. Wyrzykowski, Pojęcie interesu..., p. 33.

5 A. Żurawik, „Interes publiczny”..., pp. 61-62.

16 A. Slade, The Objectives and Principles of the WTO TRIPS Agreement: A Detailed Anatomy, "Osgoode Hall Law Journal” 2016/53, p. 984 (footnotes omitted).

17 A. Żurawik, ,Interes publiczny”..., pp. 57-69.

18 Regarding the concept of interpretation in the doctrine of Polish law see in particular: Z. Ziembiński, Problemy podstawowe prawoznawstwa [Eng. Basic Problems of Jurisprudence], Warszawa 1980; M. Zieliński, Wyktadnia prawa. Zasady-Reguty-Wskazówki [Eng. Interpretation of Law. Principles-Rules-Directions], Warszawa 2017; M. Zieliński, Wspótczesne problemy wyktadni prawa [Eng. Contemporary Problems of Interpretation of the Law], "Państwo i Prawo" 1996/8-9, pp. 5-15; J. Wróblewski, Rozumienie prawa i jego wyktadnia [Eng. Understanding of the law and its interpretation], Wrocław 1990; K. Opałek, J. Wróblewski, Zagadnienia teorii prawa [Eng. Issues of Legal Theory], Warszawa 1969; T. Gizbert-Studnicki, Wyktadnia celowościowa [Eng. Teleological Interpretation], "Studia Prawnicze” 1985/3-4, pp. 51-70; K. Płeszka, T. Gizbert-Studnicki, Dwa ujęcia wykładni. Próba konfrontacji [Eng. Two Approaches Toward the Interpretation of Law (an Attempt of Confrontation)], “Zeszyty Naukowe Uniwersytetu Jagiellońskiego" 1984/20, pp. 17-27; K. Płeszka, Uzasadnianie decyzji interpretacyjnych przez ich konsekwencje [Eng. Justifying Interpretative Decisions by Their Consequences], Kraków 1996; K. Płeszka, Wyktadnia rozszerzająca [Eng. A Broadening Interpretation], Warszawa 2010; R. Sarkowicz, Poziomowa interpretacja tekstu prawnego [Eng. Horizontal Interpretation of the Legal Text], Kraków 1994; M. Smolak, Wyktadnia celowościowa z perspektywy pragmatycznej [Eng. Teleological Interpretation from a Pragmatic Perspective], Warszawa 2012; L. Morawski, Zasady wyktadni prawa [Eng. Principles of Interpretation of Law], Toruń 2006; L. Leszczyński, B. Wojciechowski, M. Zirk-Sadowski, Wyktadnia w prawie administracyjnym [Eng. Interpretation in Administrative Law], in: R. Hauser, Z. Niewiadomski, A. Wróbel (eds.), System prawa administracyjnego [Eng. System of Administrative Law], Vol. 4, Warszawa 2012; M. Herman, S. Sykuna (eds.), Wyktadnia prawa. Tradycja i perspektywy [Eng. Interpretation of Law. Tradition and Perspectives], Warszawa 2016. 
details, for the purposes of our considerations, we will refer to the basic understanding of the public interest. We point out possible theoretical aspects only to the extent that we deem it necessary for the clarity of our text and because of academic reliability.

The definition of public interest can be found in literature on the subject. Accordingly, it is identified as

the normative duty guideline determining the scope and content of values recognized by a given community as worthy of being protected, regardless of individual beliefs of individuals. From the perspective of actions taken by the state, the concept of public interest is the limit of permissible interference of the public authority in social and economic relations and in the freedom of citizens, and from the point of view of citizens - the limit of freedom of individual activity ${ }^{19}$.

The concept of public interest exists both in international and national law. When it comes to the Polish law, it is one of the basic principles of public law, in particular administrative and economic law ${ }^{20}$. In the case of the former, it is even assumed that "when attempting to define the concept of public administration or to determine its features (characteristic, typical, basic), the principle of public interest should be mentioned as the element that typifies its essence"21. Moreover, the Polish law makers have already provided for the principle of public interest in the Polish Constitution ${ }^{22}$. For example, in relation to economic freedom, its restriction is permissible only by statute and only on grounds of important public interest ${ }^{23}$. Everyone, however, "has the right to submit petitions, applications and complaints in the public interest" 24 , and certain state bodies, such as the National Broadcasting Council, safeguard "freedom of expression, the right to information and the public interest" 25 . In addition, the Polish lawmaker allows "to create professional self-governments, representing persons exercising the profession of public trust and overseeing the proper performance of these professions within the limits of the public interest and for its protection" ${ }^{26}$. It is also worth emphasizing that public interest plays an important role also in specialized areas of Polish law. This is the case, for example, with the banking law and, particularly relevant from the perspective of this article, intellectual property law ${ }^{27}$.

In an attempt to analyse the nature, understanding, and the use of the concept of public interest, one can begin with the interpretation of each of the words forming this phrase and on this basis strive to decode all its meanings ${ }^{28}$. This approach is theoretically

19 J. Nawrot, Interes publiczny [Eng. Public Interest], in: A. Powałowski (ed.), Leksykon prawa gospodarczego publicznego. 100 podstawowych pojęć [Eng. Lexicon of Public Economic Law. 100 Basic Concepts], Warszawa 2014, p. 73.

20 See: J. Boć, Prawo administracyjne [Eng. Administrative Law], Wrocław 2000; A. Żurawik, Interes publiczny w prawie gospodarczym [Eng. Public Interest in Business Law], Warszawa 2013.

21 E. Komierzyńska, M. Zdyb, Klauzula interesu publicznego w działaniach administracji publicznej [Eng. Public Interest Clause in Public Administration Activities], "Annales Universitatis Mariae Curie-Skłodowska” 2016/2, p. 161.

22 The Constitution of the Republic of Poland 2 April 1997 (Polish title: Konstytucja Rzeczypospolitej Polskiej z 2.04.1997 r., Dz. U. Nr 78, poz. 483 ze zm.), hereinafter: "the Constitution”.

23 Article 22 of the Constitution.

24 Article 63 of the Constitution.

25 Article 213 of the Constitution.

26 Article 17 of the Constitution.

27 L. Góral, Interes publiczny jako przestanka ingerencji państwa w sferę funkcjonowania rynku bankowego w Polsce $i$ we Francji [Eng. Public Interest as a Premise for State Interference in the Sphere of the Banking Market in Poland and France ], „Studia Prawno-Ekonomiczne” 2010/82, pp. 53-68; A. Michalak, Interes publiczny i jego oddziatywanie na powstanie, treść $i$ wykonywanie praw wtasności intelektualnej [Eng. Public Interest and Its Impact on the Emergence, Content and Exercise of Intellectual Property Rights], Warszawa 2012.

28 Very interesting considerations of Justyna Michalska deserve attention in this respect. The author first introduces to the readers the Latin source of the word interest, namely interests, which means "to do something", "to participate", "to be present". Then, based on literature, the author describes three basic understandings of the concept of 
interesting, however, it will not be of much importance for our considerations. It seems much more valuable in substantive terms to attempt to define public interest by contrasting it against the individual interest. This is the approach adopted in this paper.

Three models are distinguished in legal writings pertaining to this area, namely a model referred to as the theory of superiority, the theory of common interest and the theory of unitary conception. As summarized by Justyna Nawrot, in the first case,

it is assumed that it is possible to determine public interest on the basis of individual interests in society, with public interest being the sum of the individual interests mentioned above, which are represented by the majority. The second model, existing in the literature on the subject under the name of "common interest theory" also refers to the interests of individuals. It differs from the theory of the superiority of public interest in that it assumes the sum of all individual interests while taking into account the interests of minorities, while the so-called superiority theory allows the possibility of eliminating minority interests in the process of defining the common good. The last of the mentioned models, the theory of unitary conception, differs significantly from the other two. According to its assumptions, the concept of public interest is based on the rivalry of competing claims based, however, on certain common values functioning in society and constituting the basis for the decisions of public authorities ${ }^{29}$.

The notion of public interest cannot probably be defined once and for all. Despite attempts at constructing a firm definition, it will always remain an open question how to understand it at a particular political, economic and social moment. Public interest is relative in the sense that explaining its essence requires taking into account the current social context, which is susceptible to change over time ${ }^{30}$.

What is more, there is no well-established consensus on the legal nature of public interest. As we have already mentioned, despite the frequent use of this category by the legislator, especially in public law, there are still different views on the qualification of this phrase in the doctrine. Of course, there are voices recognizing it as a strictly normative category, but also those that connect it with sociological or even political categories $^{31}$. Regardless of the above uncertainties, for the purposes of this study "in light of its use by the legislator (including the constitutional legislator), it is impossible to deny that public interest is a category of legal concept" 32 .

From the perspective of the principles of legislative technique, public interest is a general clause. Depending on the desired goal, the legislator will use legislative technique instruments aimed at either making the legal text more precise or more flexible. General clauses serve the latter purpose. The legislator often deliberately avoids unequivocally addressing certain issues at the stage of legislation and leaves it to law-applying bodies.

interest adopted in the doctrine. Generally speaking, the first theory combines the basis of interest with a certain value. The other connects the basis of interest with a need or set of needs. Finally, the third (praxeological) theory combines the basis of interest with the category of purpose. See: J. Michalska, Znaczenie interesu publicznego $w$ zakresie realizacji prawa do petycji [Eng. The Importance of the Public Interest in the Exercise of the Right of Petition], in: R. Balicki, M. Jabłoński (eds.), Teoretyczne i praktyczne aspekty realizacji prawa petycji [Eng. Theoretical and Practical Aspects of the Exercise of the Right of Petition], Wrocław 2015, pp. 47-48.

29 J. Nawrot, Interes publiczny, pp. 74-75, quoting: V. Held, The Public Interest and Individual Interests, New York 1970.

30 M. Wyrzykowski, Pojęcie interesu..., pp. 45-47, quoted by: M. Stefaniuk, , Ważny interes (publiczny, spoteczny, państwa)” jako warunek odstepstwa od zasady zachowania odpowiedniej vacatio legis [Eng. "Important (Public, Social, State) Interest" as a Condition for Departing from the Principle of maintaining adequate vacatio legis], in: M. Aleksandrowicz, A. Jamróz, L. Jamróz (eds.), Demokratyczne państwo prawa. Zagadnienia wybrane [Eng. Democratic State Ruled by Law. Selected Issues], Białystok 2014, p. 119.

31 E. Modliński, Pojęcie interesu publicznego w prawie administracyjnym [Eng. The Notion of Public Interest in Administrative Law], Warszawa 1932, p. 3, quoted by: A. Żurawik, „Interes publiczny”..., p. 57.

32 A. Borkowski, Interes publiczny..., p. 444. 
Thus, the lawmaker also launches overt decision-making play by creating a certain range of decision-making freedom. It reflects the rationality of the legislator, who should also be aware that the legal text quite often becomes "inadequate" given the changing political, social or economic reality. Assuming trust in law enforcement bodies, general clauses offer an excellent instrument for correcting the above-mentioned deficiencies. It can even be more broadly pointed out that, by means of general clauses, "the legislator communicates with the addressees of the norms as to whether non-legal criteria are included in decisions to apply the law or in compliance with the law"33.

It is assumed in the German and Polish jurisprudence that a general clause is a phrase contained in a legal provision that refers to a system of opinions or norms, however, other than a system of legal norms ${ }^{34}$. The system to which the general clause refers should be axiologically justified. The provision containing the general clause authorizes and at the same time imposes an obligation upon the given authority applying the law to handle a specific case. In a theoretical approach, the general clause is accepted, not the wording itself, but the entire legal provision containing the authorization.

At this point, general clauses should be distinguished from unclear language phrases. The latter also produces a more flexible legal text and, consequently, offers a decision-making flexibility. However, in their construction, which is easy to see, they do not refer to any extrajudicial system of values or norms.

Summing up these theoretical remarks, we can assume after Leszek Leszczyński that

a general referring clause is a norm reconstructed from the given provision (as part of it), authorizing the subject to apply the right to take into account the criterion (which imposes the obligation to take into account the need for such consideration) when qualifying a given factual state or determining its normative consequences. The name of the criterion itself, subject to a separate interpretation, referring to the determination of the type of value (moral, political, economic, included in the general social or individual context, etc.) or facts (established habits), being part of the clause, determines the type of non-legal reference and the resulting direction in the course of operational interpretation (as part of the law application process) ${ }^{35}$.

The depicted concept of public interest, qualified as a general clause,

requires an assessment of individual behaviours or decisions that are possible under certain circumstances from the point of view of the degree of implementation. As noted by T. Pietrzykowski, such concepts are created in order to avoid making decisions in abstracto about what behaviour in particular situations will be appropriate, and to leave the decision in concreto to the entity having in a given situation act in the public interest. There is no doubt that, in a democratic order, a key role in defining what kind of activities are in the public interest is played by the rivalry of individual parties, groups or political forces. The political dispute is at least ex hypothesi a dispute about the understanding and implementation of competing visions of the public interest, including how the concept should be concretized and operationalized ${ }^{36}$.

33 L. Leszczyński, Klauzule generalne odsytające - ujęcie teoretycznoprawne [Eng. General Referral Clauses - Theoretical and Legal Approach], "Annales Universitatis Mariae Curie-Sklodowska” 2016/2, p. 13.

34 On general clauses see the classic position of German literature: J. Hedemann, Die Flucht in die Generalklauseln. Eine Gefahr für Recht und Staat [Eng. Escape to the General Clauses. A danger to Law and the State], Tübingen 1933. In Polish literature see in particular: L. Leszczyński, Klauzule generalne w stosowaniu prawa [Eng. General Clauses in the Application of Law], Lublin 1986; L. Leszczyński, Tworzenie generalnych klauzul odsylających [Eng. Creating General Referral Clauses], Lublin 2000; Z. Ziembiński, Stan dyskusji nad problematyka klauzul generalnych [Eng. State of Discussion on the Issues of General Clauses], "Państwo i Prawo"1989/3, p. 14.

35 L. Leszczyński, Klauzule generalne..., pp. 13-14.

36 I. Bogucka, T. Pietrzykowski, Etyka w administracji publicznej [Eng. Ethics in Public Administration], Warszawa 2015, pp. 187-188. 
Accepting the aforementioned guidelines, it can be stated that "the responsibility of supervising the public interest includes the obligation to respect the rule of law and careful observance of the law in all taken actions" 37 .

\section{Human rights as an instrument for balancing the protection of public and private interests}

One can argue that in case of the collision between the protection of property interests and the protection of health, and thus life, the former of these values should yield to the latter. In English, the phrase "hard cases" is often used to describe such complicated issues ${ }^{38}$. Although originally, mainly due to the legacy of Ronald Dworkin, it occurred primarily in the culture of common law, where it only referred to the application of the law $^{39}$, in the Polish literature it became accepted to discuss hard cases in the broad sense of the term ${ }^{40}$. According to Jerzy Zajadło, it is hard to find a more spectacular area for the formation of "hard cases" than that which applies to the fundamental problems of human life and at the same time creates the need to formulate new ethical and legal standards. In this sense, the collision of law with medicine is a multifaceted issue and affects economics and science ${ }^{41}$. From the perspective of the hard cases theory, there is still the problem of maintaining homeostasis between the right to protect interests resulting from intellectual activity and the freedom to use its results or the right to health ${ }^{42}$. It is particularly important to discuss the possible range of restriction of intellectual property rights resulting from the need to protect public interest or ensure the pre-eminence of human rights protection over agreements and economic policies pertaining to intellectual property protection ${ }^{43}$.

Although both intellectual property rights and human rights are rooted in the philosophical concepts underlying social change of the second half of the 20th century, and the dynamic internationalization of standards relating to these rights took place after the Second World War, both fields of law evolved separately for a long time. This was, largely, due to their differences: human rights are of a public nature, while intellectual property rights are private. It can be noted both in the literature ${ }^{44}$ and in the relevant

37 I. Bogucka, T. Pietrzykowski, Etyka ..., p. 188. See: S. Sykuna, Wykonywanie zadań publicznych [Eng. Performing Public Tasks], in: R. Hauser, Z. Niewiadomski, A. Wróbel (eds.), System..., Vol. 13, Warszawa 2016, p. 296.

38 D.E. Lee, Freedom vs. Intervention: Six Tough Cases: Six Hard Cases, Lanham 2005. See also: M. Barczewski, S. Sykuna, ACTA and access to medicines in the perspective of theory of hard cases, in: J. Rosén (ed.), Intellectual Property at the Crossroads of Trade, Cheltenham-Northampton 2012, pp. 266-271.

39 M. Zirk-Sadowski, Wprowadzenie [Eng. Introduction], in: R. Dworkin, Imperium prawa [Eng. The Absolute Power of Law], Warszawa 2006, p. XIV; B. Wojciechowski, Rozstrzyganie tzw. trudnych przypadków poprzez odwołanie się do odpowiedzialności moralnej [Eng. Solving Hard Cases by Appealing to Moral Responsibility], "Studia Prawno-Ekonomiczne" 2004/70, p. 11; S. Sykuna, J. Zajadło, "Sprawy konstytucyjne” w integralnej filozofii prawa Ronalda Dworkina [Eng. "Constitutional Matters" in the Integral Philosophy of Law of Ronald Dworkin], "Gdańskie Studia Prawnicze" 2004/12, pp. $279-293$.

40 M. Barczewski, S. Sykuna, ACTA - geneza i podstawowe problemy [Eng. ACTA - Genesis and Fundamental Problems], "Państwo i Prawo" 2012/4, pp. 10-11; J. Zajadło, Po co prawnikom filozofia prawa? [Eng. Why Do Lawyers Need Philosophy of Law?), Warszawa 2008; S. Sykuna, J. Zajadło, Towards a New Theory of Hard Cases, in: B. Wojciechowski, K. Cern, P. Juchacz (eds.), Legal Rules, Moral Norms and Democratic Principles, Frankfurt am Main 2013, pp. 133-162.

${ }^{41}$ J. Zajadło, Prawo kontra medycyna [Eng. Law vs. Medicine], in: J. Zajadło (ed.), Fascynujące ścieżki filozofii prawa [Eng. Fascinating Paths of the Philosophy of Law], Warszawa 2008, p. 132.

42 M. Barczewski, Intellectual Property..., pp. 18-19.

43 M. Barczewski, S. Sykuna, ACTA..., pp. 12-14.

44 For example: L.R. Helfer, Human Rights and Intellectual Property: Conflict or Coexistence?, "Minnesota Journal of Law, Science \& Technology" 2003/5, p. 47ff; P.K. Yu, Reconceptualizing Intellectual Property Interests in a Human Rights Framework, "U.C. Davis Law Review" 2007/40, p. 1039ff; X. Seuba, Mainstreaming the TRIPS and human rights interactions, in: C.M. Correa (ed.), Research Handbook on the Protection of Intellectual Property under WTO Rules, Cheltenham-Northampton 2010, p. 192ff; P.K. Yu, Intellectual Property and Human Rights in the Nonmultilateral Era, "Florida Law Review" 2012/4, pp. 1083-1096. 
UN documents ${ }^{45}$ that there are, and there may be, significant contradictions between universal protection of intellectual property rights and the protection of economic, social and cultural rights ${ }^{46}$.

The Committee on Economic, Social and Cultural Rights noted that "human rights are different from intellectual property rights, because the former derive their existence from the human person, while the latter are instrumental in nature, as they serve to stimulate creativity and inventiveness, used by the general public". The Committee also believes that "while the human rights focus on ensuring satisfactory standards of human welfare and prosperity, the intellectual property system, although usually provides protection to individual authors, increasingly focuses on the protection of investments and corporate interests" ${ }^{\prime 47}$. For this reason, the Committee emphasized that the parties to the International Covenant on Economic, Social and Cultural Rights ${ }^{48}$ have an obligation to ensure at least the basic level of protection of the rights set out therein, and in particular the right to health, food, and education ${ }^{49}$.

Yet, the prospect of recognizing human rights and intellectual property rights as two opposing agendas, although attractive, carries the need to clarify certain ambiguities. It should be noted that certain categories of human rights, such as prohibition of torture and slavery, are widely regarded as dominant over obligations resulting from treaty regulations. Consequently, any system of intellectual property rights that hinders the fulfilment of the obligation to protect the right to health must be regarded as incompatible with the provisions of the Pact ${ }^{50}$. Therefore, due to their fundamental nature, obligations to protect human rights take privilege over agreements of a commercial nature ${ }^{51}$, which also includes the TRIPS Agreement ${ }^{52}$. Nonetheless, it should be noted that although we intuitively assume that patent rights limit the availability of medicines, without the protection resulting from intellectual property rights, many drugs which have contributed significantly to improving public health and lengthened the average life span of patients globally would not have been created ${ }^{53}$.

In this context, the important role of human rights seem to come to the forefront: they are an instrument for the prevention of abuse of intellectual property rights and the restoration of their balance, taking into account the interests of both the beneficiaries of protection and the general public ${ }^{54}$. The need for maintaining balance was noticed by the Committee on Economic, Social and Cultural Rights, which emphasized that:

45 Intellectual property rights and human rights. Sub-Commission on Human Rights resolution 2000/7 (E/CN.4/Sub.2/ RES/2000/7), United Nations Office of the High Commissioner for Human Rights, pt. 11; Substantive Issues Arising in the Implementation of the International Covenant on Economic, Social and Cultural Rights. Human Rights and Intellectual Property (E/C.12/2001/15), United Nations Committee on Economic Social and Cultural Rights, 14.12.2001.

46 M. Barczewski, Intellectual Property..., p. 171.

47 Substantive Issues... (E/C.12/2001/15), pt. 6.

48 International Covenant on Economic, Social and Cultural Rights of 19 December 1966.

49 M. Barczewski, Intellectual Property..., p. 172.

50 Substantive Issues... (E/C.12/2001/15), pt. 12.

51 Intellectual property rights... (E/CN.4/Sub.2/RES/2000/7), pt. 3. Also: P.L.C. Torremans, Copyright (and Other Intellectual Property Rights) as a Human Right, in: P.L.C. Torremans (ed.), Intellectual Property and Human Rights, New York 2008, pp. 195-196; R. Elliott, TRIPS and Rights: International Human Rights Law, Access to Medicines, and the Interpretation of the WTO Agreement on Trade-Related Aspects of Intellectual Property Rights, 2001, pp. 27-32; H. Hestermeyer, Human Rights and the WTO: The Case of Patents and Access to Medicines, Oxford 2007, p. 158.

52 M. Barczewski, Intellectual Property..., p. 173.

53 See: M.J. Adelman, Compulsory Licensing of Drugs: TRIPS Context, http://www.atrip.org/Content/Activities/s02-Adelman_art.doc, accessed on: 29 November 2016.

54 M. Barczewski, Intellectual Property..., p. 174. See also: Ch. Geiger, Fundamental Rights, a Safeguard for the Coherence of Intellectual Property Law?, "International Review of Intellectual Property and Competition Law” 2004/35, p. 278ff. 
Article 15 of the Covenant describes the need to balance the protection of public and private interests in the field of knowledge. On the one hand, Article 15.1 (a) and (b) recognizes the right of everyone to participate in cultural life and enjoy the benefits of scientific progress. On the other hand, Article 15.1 (c) recognizes the right of everyone to the enjoy the protection of the moral and material profits resulting from any scientific, literary or artistic production of which he is the author. While adopting and modifying the intellectual property systems, countries should bear in mind the need to maintain a balance between these provisions of the Covenant. In order to encourage creativity and innovation, individual interests should not be unduly favoured and public interests, consisting of broad access to knowledge, should be duly taken into account ${ }^{55}$.

\section{Interpretation and implementation of the TRIPS Agreement as a means of strengthening the right to public health}

Many of the provisions of the TRIPS Agreement are referred to as "constructively ambiguous", because, as an effect of compromise between the negotiating countries, the terms and phrases used in the provisions were deliberately not clearly defined, leaving room for interpretation in national $\mathrm{law}^{56}$. In Article 3 clause 2 of Understanding on rules and procedures governing the settlement of disputes ${ }^{57}$ it was therefore indicated that the interpretation of agreements shaping the WTO should be made in accordance with the customary principles adopted in public international law. Referring to the standards stemming from Articles 31 and 32 of the Vienna Convention on the Law of Treaties ${ }^{58}$, it should be assumed that the context used for the correct interpretation of the TRIPS Agreement is primarily its entire content, including the preamble, as well as Articles 7 and 8, which define the objectives and principles of the Agreement, respectively ${ }^{59}$.

As Peter K. Yu points out ${ }^{60}$, these two provisions codify the multilateral norms concerning the protection of the public interest in intellectual property law ${ }^{61}$. As such, they "qualify the scope of harmonization of intellectual property standards at the national level" ${ }^{2}$. Article 7 of the TRIPS Agreement sets out the objectives of the agreement, stating that

the protection and enforcement of intellectual property rights should contribute to the promotion of technological innovation and to the transfer and dissemination of technology, to the mutual advantage of producers and users of technological knowledge and in a manner conducive to social and economic welfare, and to a balance of rights and obligations.

\footnotetext{
55 Substantive Issues... (E/C.12/2001/15), pt. 17. There is a prevailing view that the beneficiaries of the protection provided for in Article 15(1) of the Covenant on Economic, Social and Cultural Rights are creators that are natural persons, and not legal entities, such as pharmaceutical companies - General Comment No. 17 (E/C.12/GC/12), United Nations Committee on Economic, Social and Cultural Right, 12 January 2006, pt, 7; H. Hestermeyer, Human Rights..., p. 155; P. Xiong, An International Law Perspective on the Protection of Human Rights in the TRIPS Agreement. An Interpretation of the TRIPS Agreement in Relation to the Right to Health, Leiden 2012, p. 265.

56 M. Barczewski, Intellectual Property..., p. 73.

57 Annex 2 of the WTO Agreement.

58 Vienna Convention on the Law of Treaties prepared in Vienna on 23 May 1969, hereinafter: "Vienna Convention".

59 M. Barczewski, Intellectual Property..., pp. 73-74.

${ }_{60}$ P.K. Yu, The Objectives and Principles of the TRIPS Agreement, "Houston Law Review" 2009/46, p. 1019.

61 A.A. Yusuf, TRIPS: Background, Principles and General Provisions, in: C.M. Correa, A.A. Yusuf (eds.), Intellectual Property and International Trade: The TRIPS Agreement, New York 2008, p. 12.

${ }^{62}$ A.A. Yusuf, TRIPS: Background..., p. 14.
} 
Furthermore, the principles expressed in Article 8 allow member states of the WTO to adopt, in formulating or amending their laws and regulations, "measures necessary to protect public health and nutrition, and to promote the public interest in sectors of vital importance to their socio-economic and technological development" ${ }^{\prime 3}$. In the context of the problem of access to medicines it therefore requires special emphasis on highlighting the importance of that provision in the interpretation and subsequent implementation of the TRIPS Agreement norms need to protect public health.

Use of general and imprecise concepts, such as "public health" or "national emergency" in the TRIPS Agreement, encourages, based on the relevant provisions of the Vienna Convention, references to other treaty regulations in the interpretation process, especially those regarding the protection of human rights. Thus, if we accept a broader conceptual referent of "national emergency" that would include serious public health emergencies arising from infectious disease epidemics, the possibilities to limit or repeal patent protection based on that provision due to the need to ensure protection of health cannot be excluded ${ }^{64}$. As noted by Jerome H. Reichman, in principle, both the public interest exception and measures to prevent abuse, stipulated in Article 8 of the TRIPS Agreement, could justify resort to compulsory licensing ${ }^{65}$. For example, this kind of broad interpretation of the concept of national emergency became the basis for the introduction of a compulsory licensing system in Brazil in the late 1990s, which helped reduce the number of HIV/AIDS cases in that country by more than a half ${ }^{66}$.

The possibility of compulsory licensing was allowed as early as in 1958 by the Paris Convention ${ }^{67}$. In accordance with the current wording of Article 5A thereof, the parties to the Convention may issue compulsory licenses and determine the conditions for their application "to prevent abuses which might result from exercising exclusive rights conferred by a patent, for example, failure to work". In 1982, the demands from developing countries which pursued to introduce the system of compulsory licenses led to a crash of the negotiations over the adoption of another revision of the convention ${ }^{68}$. Within the framework of the TRIPS Agreement, Articles 30 and 31 lay down a set of conditions for issuing compulsory patent licenses. While Article 30 allows for exceptions of rights conferred by a patent provided they "limited", "do not unreasonably conflict with normal exploitation of the patent and do not unreasonably prejudice the legitimate interests of the patent owner" and "take into account the legitimate interests of third parties", Article 31 does not mention the need to meet such conditions to use the subject matter of a patent without the authorization of the right holder. It specifies the possible use of the subject matter of a patent through the introduction of compulsory

${ }^{63}$ According to Gillian Davis, "whether a particular act is "in the public interest" (...) is probably not subject to any objective tests. Inherent in the noble motive of the public good is the notion that, in certain circumstances, the needs of the majority override those of the individual, and that the citizen should relinquish any thoughts of self-interest in favor of the common good of society as a whole". G. Davies, Copyright and the Public Interest, London 2002, p. 4.

${ }^{64}$ H. Hestermeyer, Human Rights..., pp. 287-288.

65 J.H. Reichman, Universal Minimum Standards of Intellectual Property Protection under the TRIPS Component of the WTO Agreement, in: C. M. Correa, A.A. Yusuf (eds.), Intellectual Property..., p. 34.

${ }_{66}$ The impact of the Agreement on Trade-Related Aspects... (E/CN.4/Sub.2/2001/13), pt. 57. See: J. Galvão, Brazil and Access to HIVIAIDS Drugs: A Question of Human Rights and Public Health, "American Journal of Public Health" 2005/7, pp. 1110-1116; D. Matthews, When Framing Meets Law: Using Human Rights as a Practical Instrument to Facilitate Access to Medicines in Developing Countries, “The WIPO Journal” 2011/2, pp. 119-123.

67 The Stockholm Act changing the Convention for the Protection of Industrial Property in Paris of 20 March 1883, changed in Brussels on 14 December 1900, in Washington on 2 June 1911, in Hague on 6 November 1925, in London on 2 June 1934, in Lisbon on 31 October 1958, and drawn up in Stockholm on 14 July 1967.

68 J. Watal, Intellectual property rights in the WTO and developing countries, New York 2001, p. 17. 
licenses ${ }^{69}$. It is assumed that they should not be granted just upon the patent holder's refusal to allow the use of an invention. Against the background of Article 7 and Section 4 of the preamble to the TRIPS Agreement, the rights and obligations must not be balanced by means of weakening the protection of patent holders without consideration for the interest of the society as a whole. Thus, it is assumed that only broadly understood public interest can legitimize the issuance of compulsory licenses ${ }^{70}$.

Furthermore, the need to interpret and implement the TRIPS Agreement in a way that supports the right to protect public health was expressed directly in the Declaration on the TRIPS Agreement and Public Health of 14 November 200171. Member states of the WTO agreed in paragraph 4 of the Declaration that the TRIPS Agreement does not and should not prevent members from taking measures to protect public health. Accordingly, its signatories affirmed that the Agreement can and should be interpreted and implemented in a manner supportive of WTO members' right to protect public health and, in particular, to promote access to medicines for all. They also recognized that each provision of the TRIPS Agreement should be read in the light of the object and purpose of the Agreement as expressed, in particular, in its objectives and principles (set out in Articles 7 and 8).

Furthermore, the Declaration acknowledged that WTO members with insufficient or no manufacturing capacities in the pharmaceutical sector could face difficulties in making effective use of compulsory licensing. Therefore, it was put into practice in 2003 by the WTO with a decision enabling countries that cannot manufacture medicines themselves, to import pharmaceuticals made under compulsory licences ${ }^{72}$. In 2005, Members agreed to make this decision permanent through a Protocol Amending the TRIPS Agreement ${ }^{73}$, which entered into force on 23 January 2017. This amendment provided legal certainty that generic versions of patent-protected medicines can be manufactured under compulsory licences specifically for export to countries with limited or no pharmaceutical manufacturing capacity ${ }^{74}$.

It can therefore be assumed that, by clarifying interpretative doubts, the Declaration on the TRIPS Agreement and Public Health has contributed to increasing the legal certainty of WTO members with regard to the application of the TRIPS Agreement standards, in particular in the field of protection of medicines. Its persuasiveness in this respect is comparable to the indications resulting from Articles 7 and 8 of the TRIPS Agreement and led to the strengthening of WTO members' freedom in the field of public health protection.

\section{Concluding remarks}

Advocates of strong intellectual property protection invoke the prospect of material reward as a key argument to justify the existence and validity of intellectual property rights. Under this approach, strongly rooted in the doctrine of utilitarianism, the

69 M. Barczewski, Intellectual Property..., p. 109.

70 N. Pires de Carvalho, The TRIPS Regime of Patent Rights, New York 2010, p. 436.

71 Declaration on the TRIPS Agreement and Public Health (WT/MIN (01)/DEC/2), WTO, 14 November 2001.

72 Implementation of Paragraph 6 of the Doha Declaration on the TRIPS Agreement and Public Health. Decision of 30 August 2003 (WT/L/540), WTO, 2 September 2003.

73 Amendment of the TRIPS Agreement. Decision of 6 December 2005 (WT/L/641), WTO, 8 December 2005.

74 Intellectual Property and the Public Interest... (IP/C/W/630), pt. 5. 
prospect of receiving remuneration is to motivate intellectual activity ${ }^{75}$. As a result, all intellectual property law norms reflect the intention to protect the interests of, first and foremost, entities based in industrialized countries, only partly taking into account the conditions of less developed countries related to the need for unrestricted access to cultural heritage or health protection ${ }^{76}$.

On the other hand, as rightly noted by A. Slade,

primary justification for intellectual property protection is the value it holds for the dissemination of knowledge and the transfer of technology both nationally and internationally. The utility of the intellectual property system rests not merely in protecting the interests of the rights holder, but in doing so for the wider public interest. Moreover, the protection of intellectual property is often premised upon social contract theories: society grants the inventor or creator a selection of exclusive rights and in return, the inventor or creator grants full disclosure - the "intellectual property bargain". Thus, the system is of wider interest to society, which is now free to use that knowledge and information (albeit subject to the requisite licensing arrangements). This use in turn fosters further innovation, creation, and improvement ${ }^{77}$.

According to the prevailing view, utilitarian approach has been adopted as a standard in international IP norm setting, i.e. creations of the human mind are necessary for the development of society and various forms of a reward are deemed to be the incentive for such creative activity ${ }^{78}$. This approach influenced most of the international IP related agreements, including the TRIPS Agreement ${ }^{79}$. Yet, it is difficult to ignore the fact that over-reliance on utility-maximization ignores distributional consequences and equality concerns are second order concerns to efficiency norms ${ }^{80}$. In such a spectacular plane of collision between the protection of property interests and the protection of health, and therefore life, we are faced with the need to formulate new ethical and legal standards.

Undoubtedly, there is a public interest in defining the boundaries of IP-related components that determine access to medicines. As noted above, the meaning of public interest depends on the current social context in the sense of achieving specific values accepted and desired in a given society at a given time. One of the essential measures that can contribute to accomplishing these goals is the broadest possible use of compulsory licenses, also with respect to the results of preclinical and clinical trials. Another instrument is the process of interpretation of the TRIPS Agreement which aims at not only explaining or clarifying the meaning of the provisions or determining the intentions of the parties to the treaty, but also at reconciling the underlying competing goals and objectives of this Agreement ${ }^{81}$. The need to interpret and implement its provisions in a way that protects public interest by facilitating universal access to medicines is confirmed by the obligation of acting "in a manner conducive to social and economic welfare" under Article 7 of the TRIPS Agreement. Moreover, Article 8 allows to adopt

\footnotetext{
75 M. Barczewski, Wtasność intelektualna na tle teorii sprawiedliwości Johna Rawlsa [Eng. Intellectual Property Against the Background of John Rawls' Theory of Justice], “Gdańskie Studia Prawnicze” 2016/35, pp. 77-78.

76 M. Barczewski, Wtasność intelektualna ..., p. 78.

77 A. Slade, The Objectives..., p. 967 (footnotes omitted).

78 M. Barczewski, D. Pyć, Intellectual property and sustainable development: a distributive justice perspective, in: G. Dinwoodie (ed.), Methods and Perspectives in Intellectual Property, Cheltenham-Northampton 2013, p. 208.

79 P. Kameri-Mbote, J. Otieno-Obek, Genetic use restriction technologies and sustainable development in eastern and southern Africa, in: R. Meléndez-Ortiz, P. Roffe (eds.), Intellectual Property and Sustainable Development. Development Agendas in a Changing World, Cheltenham-Northampton 2009, p. 216.

80 M. Chon, Intellectual Property and the Development Divide, “Cardozo Law Review” 2006/6, p. 2824.

81 P. Xiong, An International Law..., p. 330.
} 
"measures necessary to protect public health and nutrition, and to promote the public interest in sectors of vital importance to their socio-economic and technological development". Therefore, when it comes to access to medicines, human rights are an important instrument for the prevention of abuse of intellectual property rights and the restoration of their balance, taking into account the interests of both the beneficiaries of protection and the general public.

\title{
Improving Global Public Health: Responsiveness to Public Interest Considerations in Intellectual Property Law
}

\begin{abstract}
Over the past few years the WTO Council for Trade-Related Aspects of Intellectual Property Rights recognized the growing concern over an imbalance between intellectual property and public interest. With regard to health technologies in particular, without sufficient use of balancing exceptions and limitations, patents and related monopoly rights primarily serve to protect corporate interests of the pharmaceutical industry. The broadest possible use of compulsory licenses is one of the essential measures that can contribute to increase in responsiveness to public interest considerations in defining the boundaries of the IP-related components that determine access to medicines. Another instrument is the process of interpretation and implementation of the Trade-Related Aspects of Intellectual Property Rights Agreement (TRIPS), which aims not only at clarifying the meaning of the provisions or determining the intentions of the parties to this treaty, but sets sights on reconciling its competing objectives. The need to interpret and implement the TRIPS Agreement in a way that protects public interest is confirmed by the obligation of acting "in a manner conducive to social and economic welfare" under Article 7 of the Agreement. Moreover, Article 8 allows to adopt "measures necessary to protect public health and nutrition, and to promote the public interest in sectors of vital importance to their socio-economic and technological development". Therefore, in the context of the problem of access to medicines, the important role of human rights as an instrument for the prevention of abuse of intellectual property rights and the restoration of their balance, taking into account the interests of both the beneficiaries of protection and the general public, should be emphasized.
\end{abstract}

Keywords: intellectual property, WTO, human rights, public interest, patents, access to medicines, TRIPS 


\section{BIBLIOGRAFIA / REFERENCES:}

Barczewski, M. (2016). Intellectual Property Rights in the WTO and Access to Medicines. Gdańsk: Gdańsk University Press.

Barczewski, M. (2016). Własność intelektualna na tle teorii sprawiedliwości Johna Rawlsa. Gdańskie Studia Prawnicze 35.

Barczewski, M., Pyć, D. (2013). Intellectual property and sustainable development: a distributive justice perspective. In: G. Dinwoodie (ed.), Methods and Perspectives in Intellectual Property. Cheltenham-Northampton: Edward Elgar Publishing.

Barczewski, M., Sykuna, S. (2012). ACTA - geneza i podstawowe problemy. Państwo i Prawo 4.

Barczewski, M., Sykuna, S. (2012). ACTA and access to medicines in the perspective of theory of hard cases. In: J. Rosén (ed.), Intellectual Property at the Crossroads of Trade. CheltenhamNorthampton Edward Elgar Publishing.

Boć, J. (red.) (2000). Prawo administracyjne. Wrocław: Kolonia Limited.

Bogucka, I., Pietrzykowski, T. (2015). Etyka w administracji publicznej. Warszawa: Wolters Kluwer Polska.

Borkowski, A. (2012). Interes publiczny a partnerstwo publiczno - prawne. In: Prawne aspekty prywatyzacji. Wrocław: Prawnicza i Ekonomiczna Biblioteka Cyfrowa.

Chon, M. (2006). Intellectual Property and the Development Divide. Cardozo Law Review 6.

Colm, G. (1962). The Public Interest: Essential Key to Public Policy. In: C.J. Friedrich (ed.), The Public Interest. New York: Atherton Press.

Davies, G. (2002). Copyright and the Public Interest. London: Sweet \& Maxwell Ltd.

de Carvalho Pires, N. (2010). The TRIPS Regime of Patent Rights. New York: Kluwer Law International.

Elliott, R. (2001). TRIPS and Rights: International Human Rights Law, Access to Medicines, and the Interpretation of the WTO Agreement on Trade-Related Aspects of Intellectual Property Rights. South Africa: AIDS Law Project.

Galvão, J. (2005). Brazil and Access to HIV/AIDS Drugs: A Question of Human Rights and Public Health. American Journal of Public Health 7.

Geiger, Ch. (2004). Fundamental Rights, a Safeguard for the Coherence of Intellectual Property Law?. International Review of Intellectual Property and Competition Law 35.

Gizbert-Studnicki, T. (1985). Wykładnia celowościowa. Studia Prawnicze 3-4.

Góral, L. (2010). Interes publiczny jako przesłanka ingerencji państwa w sferę funkcjonowania rynku bankowego w Polsce i we Francji. Studia Prawno-Ekonomiczne 82.

Hedemann, J. (1933). Die Flucht in die Generalklauseln. Eine Gefahr für Recht und Staat. Tübingen: Mohr.

Held, V. (1970). The Public Interest and Individual Interests. New York: Basic Books.

Helfer, L.R. (2003). Human Rights and Intellectual Property: Conflict or Coexistence?. Minnesota Journal of Law, Science \& Technology 5. 
Herman, M., Sykuna, S. (eds.) (2016). Wykładnia prawa. Tradycja i perspektywy. Warszawa: C.H. Beck.

Hestermeyer, H. (2007). Human Rights and the WTO: The Case of Patents and Access to Medicines. Oxford: Oxford University Press.

Kameri-Mbote, P., Otieno-Obek, J. (2009). Genetic use restriction technologies and sustainable development in eastern and southern Africa. In: R. Meléndez-Ortiz, P. Roffe (eds.), Intellectual Property and Sustainable Development. Development Agendas in a Changing World. Cheltenham-Northampton: Edward Elgar Publishing.

Komierzyńska, E., Zdyb, M. (2016). Klauzula interesu publicznego w działaniach administracji publicznej. Annales Universitatis Mariae Curie-Sktodowska 2.

Lee, D.E. (2005). Freedom vs. Intervention: Six Tough Cases: Six Hard Cases. Lanham: Rowman \& Littlefield Publishers.

Leszczyński, L. (1986). Klauzule generalne w stosowaniu prawa. Lublin: UMCS.

Leszczyński, L. (2000). Tworzenie generalnych klauzul odsyłajacych. Lublin: UMCS.

Leszczyński, L. (2016). Klauzule generalne odsyłające - ujęcie teoretycznoprawne. Annales Universitatis Mariae Curie-Skłodowska 2.

Leszczyński, L., Wojciechowski, B., Zirk-Sadowski, M. (2012). Wykładnia w prawie administracyjnym. In: R. Hauser, Z. Niewiadomski, A. Wróbel (eds.), System prawa administracyjnego. Warszawa: C.H. Beck.

Maskus, K.E. (2000). Intellectual Property Rights in the Global Economy. Washington DC: Peterson Institute for International Economics.

Matthews, D. (2005). TRIPS Flexibilities and Access to Medicines in Developing Countries: The Problem with Technical Assistance and Free Trade Agreements. European Intellectual Property Review 11.

Matthews, D. (2011). When Framing Meets Law: Using Human Rights as a Practical Instrument to Facilitate Access to Medicines in Developing Countries. The WIPO Journal 2.

Michalak, A. (2012). Interes publiczny i jego oddziaływanie na powstanie, treść i wykonywanie praw własności intelektualnej. Warszawa: C.H. Beck.

Michalska, J. (2015). Znaczenie interesu publicznego w zakresie realizacji prawa do petycji. In: R. Balicki, M. Jabłoński (eds.), Teoretyczne i praktyczne aspekty realizacji prawa petycji. Wrocław: Prawnicza i Ekonomiczna Biblioteka Cyfrowa.

Modliński, E. (1932). Pojęcie interesu publicznego w prawie administracyjnym. Warszawa: Polski Instytut Prawa Administracyjnego im. Kazimierza Wielkiego.

Montgomery, J.D. (1962). Public Interest in Ideologies of National Development. In: C.J. Friedrich (ed.), The Public Interest. New York: Atherton Press.

Morawski, L. (2006). Zasady wyktadni prawa. Toruń: TNOIK.

Nawrot, J. (2014). Interes publiczny. In: A. Powałowski (ed.), Leksykon prawa gospodarczego publicznego. 100 podstawowych pojęć. Warszawa: C.H. Beck.

Opałek, K., Wróblewski, J. (1969). Zagadnienia teorii prawa, Warszawa: PWN. 
Picciotto, S. (2003). Private Rights vs. Public Interests in the TRIPS Agreement. In: Proceedings of the Annual Meeting (American Society of International Law). Cambridge: Cambridge University Press.

Płeszka, K. (1996). Uzasadnianie decyzji interpretacyjnych przez ich konsekwencje. Kraków: Towarzystwo Autorów i Wydawców Prac Naukowych Universitas.

Płeszka, K. (2010). Wykładnia rozszerzająca. Warszawa: Wolters Kluwer Polska.

Płeszka, K., Gizbert-Studnicki, T. (1984). Dwa ujęcia wykładni. Próba konfrontacji. Zeszyty Naukowe Uniwersytetu Jagiellońskiego 20.

Reichman, J.H. (2008). Universal Minimum Standards of Intellectual Property Protection under the TRIPS Component of the WTO Agreement. In: C. M. Correa, A. A. Yusuf (eds.), Intellectual Property and International Trade: The TRIPS Agreement. New York: Kluwer Law International.

Roffe, P. (2005). Resource Book on TRIPS and Development. New York: UNCTAD.

Sarkowicz, R. (1994). Poziomowa interpretacja tekstu prawnego. Kraków: Uniwersytet Jagielloński.

Seuba, X. (2010). Mainstreaming the TRIPS and human rights interactions. In: C.M. Correa (ed.), Research Handbook on the Protection of Intellectual Property under WTO Rules. CheltenhamNorthampton: Edward Elgar Publishing.

Slade, A. (2016). The Objectives and Principles of the WTO TRIPS Agreement: A Detailed Anatomy. Osgoode Hall Law Journal 53.

Smolak, M. (2012). Wyktadnia celowościowa z perspektywy pragmatycznej. Warszawa: Wolters Kluwer Polska.

Stefaniuk, M. (2014). "Ważny interes (publiczny, społeczny, państwa)" jako warunek odstępstwa od zasady zachowania odpowiedniej vacatio legis. In: M. Aleksandrowicz, A. Jamróz, L. Jamróz (eds.), Demokratyczne państwo prawa. Zagadnienia wybrane. Białystok: Temida 2.

Sykuna, S. (2016). Wykonywanie zadań publicznych. In: R. Hauser, Z. Niewiadomski, A. Wróbel (eds.), System Prawa Administracyjnego. Warszawa: C.H. Beck.

Sykuna, S., Zajadło, J. (2004). „Sprawy konstytucyjne” w integralnej filozofii prawa Ronalda Dworkina. Gdańskie Studia Prawnicze 12.

Sykuna, S., Zajadło, J. (2013). Towards a New Theory of Hard Cases. In: B. Wojciechowski, K. Cern, P. Juchacz (eds.), Legal Rules, Moral Norms and Democratic Principles. Frankfurt am Main: Peter Lang.

Torremans, P.L.C. (2008). Copyright (and Other Intellectual Property Rights) as a Human Right. In: P.L.C. Torremans (ed.), Intellectual Property and Human Rights. New York: Kluwer Law International.

Watal, J. (2001). Intellectual property rights in the WTO and developing countries. New York: Kluwer Law International.

Wojciechowski, B. (2004). Rozstrzyganie tzw. trudnych przypadków poprzez odwołanie się do odpowiedzialności moralnej. Studia Prawno-Ekonomiczne 70.

Wróblewski, J (1990). Rozumienie prawa i jego wyktadnia. Wrocław: Zakład Narodowy im. Ossolińskich. 
Wyrzykowski, M. (1986). Pojęcie interesu społecznego w prawie administracyjnym. Warszawa: Wydawnictwo Uniwersytetu Warszawskiego.

Xiong, P. (2012). An International Law Perspective on the Protection of Human Rights in the TRIPS Agreement. An Interpretation of the TRIPS Agreement in Relation to the Right to Health. Lejda: Martinus Nijhoff.

Yu, P.K. (2007). Reconceptualizing Intellectual Property Interests in a Human Rights Framework. U.C. Davis Law Review 40.

Yu, P.K. (2009). The Objectives and Principles of the TRIPS Agreement. Houston Law Review 46.

Yu, P.K. (2012). Intellectual Property and Human Rights in the Nonmultilateral Era. Florida Law Review 4.

Yusuf, A. (2008). TRIPS: Background, Principles and General Provisions. In: C.M. Correa, A.A. Yusuf (eds.), Intellectual Property and International Trade: The TRIPS Agreement. New York: Kluwer Law International.

Zajadło, J. (2008). Po co prawnikom filozofia prawa?. Warszawa: Wolters Kluwer Polska.

Zajadło, J. (2008). Prawo kontra medycyna. In: J. Zajadło (ed.), Fascynujace ścieżki filozofii prawa. Warszawa: LexisNexis.

Zieliński, M. (1996). Współczesne problemy wykładni prawa. Państwo i Prawo 8-9.

Zieliński, M. (2017). Wykładnia prawa. Zasady-Reguty-Wskazówki. Warszawa: Wolters Kluwer Polska.

Ziembiński, Z. (1980). Problemy podstawowe prawoznawstwa. Warszawa: PWN.

Ziembiński, Z. (1989). Stan dyskusji nad problematyką klauzul generalnych. Państwo i Prawo 3.

Zirk-Sadowski, M. (2006). Wprowadzenie. In: R. Dworkin, Imperium prawa. Warszawa: Wolters Kluwer Polska.

Żurawik, A. (2013). „Interes publiczny”, „interes społeczny” i „interes społecznie uzasadniony”. Ruch Prawniczy, Ekonomiczny i Socjologiczny 2.

Żurawik, A. (2013). Interes publiczny w prawie gospodarczym. Warszawa: C.H. Beck. 